UDC 291.1

LBC 86.2

\title{
PROSPECTS FOR THE CONVERGENCE OF RELIGIOUS AND GAMING ACTIVITIES IN THE POST-SECULAR ERA
}

\author{
Dmitriy R. Javorskiy \\ Volgograd State University, Volgograd, Russian Federation
}

\begin{abstract}
The article explores the relationship between religion and play as two types of activity. The relevance of this comparison is dictated by the fact that a playful attitude to religion is fraught with conflict situations, since under certain conditions it borders on sacrilege, "insulting the feelings of believers". The author of the article proceeds from the fact that in order to clarify the boundaries and areas of intersection of religion and the game, it is advisable to clarify the concept of religion. The "classical" concept of religion, as shown by a whole series of religious studies and historical studies, is essentially Christian-centered, therefore, in order to enter a broader subject field, it requires revision. An appeal to anthropology and the history of religion shows that religious practices do not exclude, in principle, a gaming relationship. Moreover, in some historically and anthropologically fixed religions, the game is an integral part of the relationship to the superhuman world of gods and spirits. Even in the Christian tradition, remnants of the game component of religious practices remain, for example, in the form of carnivals. The author comes to the conclusion that the separation of religion from the game occurs only in Modern times, when the very concept of religion becomes clearer, and religion in scientific, political and legal discourse is separated from other activities (science, politics, art, economics, etc.). Therefore, paradoxical as it may seem at first glance, the separation of the game and religion is a side effect of secularization. The postsecular situation allows for the convergence of religion and games in a variety of forms: in the cultural and historical reconstruction of "neo-paganism", in the parody practices of "Pastafarianism", in the form of cosplay "Jedi", etc. The blurring of the boundary between religion and play in modern culture is facilitated by aesthetic practices that cultivate the so-called "post-irony" is a special communicative state in which participants are not able to accurately determine the pragmatic status of messages sent and received, and it is this discrepancy in interpretations that generates conflict situations, the theoretical understanding of which is devoted to the article.
\end{abstract}

Key words: game, carnival, cosplay, post-irony, post-secularity, religion, secularization.

Citation. Javorskiy D.R. Prospects for the Convergence of Religious and Gaming Activities in the PostSecular Era. Logos et Praxis, 2021, vol. 20, no. 3, pp. 16-26. (in Russian). DOI: https://doi.org/10.15688/lp.jvolsu.2021.3.2

УДК 291.1

ББК 86.2

\section{ПЕРСПЕКТИВЫ КОНВЕРГЕНЦИИ РЕЛИГИОЗНОЙ И ИГРОВОЙ ДЕЯТЕЛЬНОСТИ В ПОСТСЕКУЛЯРНУЮ ЭПОХУ}

\section{Дмитрий Ромуальдович Яворский}

Волгоградский государственный университет, г. Волгоград, Российская Федерация

Аннотация. В статье исследуется взаимоотношение религии и игры как двух видов деятельности. Актуальность этого сопоставления диктуется тем, что игровое отношение к религии чревато конфликтными ситуациями, поскольку при определенных условиях оно граничит со святотатством, «оскорблением чувств верующих». Автор статьи исходит из того, что для уяснения границ и областей пересечения религии и игры целесообразно уточнить понятие религии. «Классическое» понятие религии, как показала целая серия религиоведческих и исторических исследований, в сущности, христианоцентрично, поэтому для выхода на более вает, что религиозные практики не исключают в принципе игрового отношения. Более того, в некоторых 
исторически и антропологически зафиксированных религиях игра составляет неотъемлемую часть отношения к сверхчеловеческому миру богов и духов. Даже в христианской традиции сохраняются пережитки игрового компонента религиозных практик, например, в виде карнавалов. Автор приходит к выводу, что отграничение религии от игры происходит только в Новое время, когда само понятие религии становится более четким, и религия в научном, политическом и юридическом дискурсе отделяется от иных видов деятельности (науки, политики, искусства, экономики и т. п.). Поэтому, как это ни парадоксально покажется на первый взгляд, разведение игры и религии - побочный эффект секуляризации. Постсекулярная ситуация допускает конвергенцию религии и игры в самых разнообразных формах: в культурно-исторической реконструкции «неоязычества», в пародийных практиках «пастафарианства», в форме косплея «джедаистов» и т. д. Размыванию границы между религией и игрой в современной культуре способствуют эстетические практики, культивирующие так называемую «постиронию» - особое коммуникативное состояние, в котором участники не способны точно определить прагматический статус отправляемых и получаемых сообщений, и именно это расхождение в интерпретациях порождает конфликтные ситуации, теоретическому осмыслению которых посвящена статья.

Ключевые слова: игра, карнавал, косплей, постирония, постсекулярность, религия, секуляризация.

Цитирование. Яворский Д. Р. Перспективы конвергенции религиозной и игровой деятельности в постсекулярную эпоху// Logos et Praxis. - 2021. - Т. 20, № 3. - С. 16-26. - DOI: https://doi.org/10.15688/lp.jvolsu.2021.3.2

\section{Постановка проблемы}

Некоторое время назад автору статьи довелось участвовать в дискуссии по поводу рекламы, в которой были использованы видоизмененные религиозные образы и символы. В центре рекламного изображения был помещен объект, напоминающий евхаристическую чашу, в ней изображена жидкость (видимо, пиво, поскольку именно оно рекламировалось), в которой плавала льдина. По сторонам чаши располагались две мужские фигуры с крыльями, нимбами и со смартфонами на моноподах. Название продукта было выписано шрифтом, имитирующим старославянский стиль. Организатор дискуссии предложил ответить на вопрос «оскорбляет ли это изображение чувства верующих?» и аргументировать свой ответ. Как нетрудно догадаться, мнения разделились. Защитники рекламы инкриминировали своим оппонентам отсутствие чувства юмора. Оппоненты парировали, указывая на неуместность юмора в вопросах веры. Стало понятно, что участники дискуссии расходятся в главном: в вопросе - совместима ли религия с юмором, смехом и шире - игрой, или несовместима. Уместно заметить, что в изображении, по поводу которого шла дискуссия, есть признаки игры: свобода в обращении с материалом (в данном случае образами и символами) и забавность (о чем свидетельствует реакция тех, у кого изображение не вызывало возмущения) [Хёйзинга 2011].
Этот кейс, будучи рассмотренным на философском уровне, побуждает обсудить вопрос о соотношении религии и игры в широком смысле слова. Разумеется, если бы это был единичный случай, он не требовал бы такого внимания. Однако подобного рода вопросы все чаще возникают в гуще социальных практик и нередко переводятся в конфликтную плоскость, предполагающую в лучшем случае юридическое, а в худшем - политическое решение.

Позиция противников союза религии и игры в сжатом виде могла бы выглядеть следующим образом. Религия - это система (или совокупность) представлений, убеждений и регламентированных действий, в центре которых находится нечто сакральное. Как показал немецкий феноменолог религии Рудольф Отто, сакральное - то, что вызывает благоговение, священный трепет, то, что завораживает [Отто 2008]. А эти переживания и чувства несовместимы с игровой несерьезностью. Американский философ и психолог Уильям Джеймс писал по этому поводу: «Настоящая религиозность сделала бы невозможным тот легкомысленный тон, каким говорит Ренан. Она порождает серьезное отношение к жизни и исключает легкомыслие; она заставляет умолкнуть пустую, хотя бы и блестящую речь. Религия враждебна не только дерзости иронии, но и мрачному ропоту и жалобам. Для многих религий мир трагичен, но трагедия в них является очистительным моментом, не исключающем веры в конечное спасение» 
[Джеймс 2017, 31]. Немецко-американский философ и культуролог Ойген РозенштокХюсси негодовал в одной из своих лекций по сравнительному религиоведению перед студентами Дартмутского колледжа: «У меня есть коллега - еврейский господин, который сказал: "Иисус не был великим человеком, так как у него не было чувства юмора"... Юмор - это нечто вторичное. Конечно, у Него не было чувства юмора, так как Он вынужден был иметь дело с реальными вещами. У вас есть чувство юмора, потому что вы не живете, вы только смеетесь и играете. Играя вам проще иметь чувство юмора» [Rosenstock-Huessy 2005] ${ }^{1}$.

Однако эти аргументы далеко не бесспорны. С точки зрения исследователя религии, самое уязвимое место представленной аргументации - стихийное понятие религии, которое скрыто лежит в основе приведенных позиций. Как показали исследования последних десятилетий, такое понятие религии не старше XVII в. и возникло оно под влиянием социальных, политических и идеологический процессов, инициированных в недрах Реформации и Просвещения [McCutcheon 1997; Dubuisson 2003]. Важно также заметить, что это понятие сложилось не в результате отвлеченных научных дискуссий и по правилам формальной логики, а спонтанно и по принципу «семейного сходства» [Витгенштейн 1994, 111; Лакофф 2011, 32-34; Иллка Пюсиайнен... web].

Реформация, породившая ценность религиозной свободы, привела европейские нации к необходимости исключения вопросов веры из области политики, ведь именно крайняя политизация веры породила кровопролитные религиозные войны XVI-XVII вв. в Западной Европе. Но, чтобы отделить религию от политики, необходимо было сначала с юридической четкостью обозначить границы «религии». Однако средневековье не знало этих границ. «Религия» была вплетена почти во все культурные практики (семейные, профессиональные, социально-политические). По этой причине затруднительно было сходу ответить на вопрос: то, что находится перед нами имеет отношение к религии или нет? Юридически были четко прочерчены границы церкви как общественного института, но не границы «религии». Впрочем, можно сказать, что эти гра- ницы, как правило, совпадали. Именно выход религиозных практик за границы церкви (Католической церкви) в эпоху Реформации остро поставил вопрос о границах религиозного. Ревнители Американской и Французской революции XVIII в., подхватив ценность религиозной свободы, предприняли юридическое закрепление «свободы совести». Однако это также требовало конвенционального понятия религии, на которое могли бы опираться законодатели и применители права.

Неудивительно, что это понятие религии было почерпнуто из привычной европейцам практики христианских церквей. Религия стала ассоциироваться как минимум с тремя вещами: 1) с отношением человека к сверхъестественному Субъекту (или субъектам); 2) с практиками благоговения, регламентированными в ритуале; 3) с аскетическими практиками, нацеленными на «спасение души». Далее заработал описанный Л. Витгенштейном принцип образования категорий, который он назвал принципом «семейного сходства». Согласно этому принципу при образовании категории интеллект выделяет образцовый элемент множества. Свойства этого элемента задают признаки принадлежности к множеству. Например, если мы обнаруживаем в исламе отношения со сверхъестественным субъектом и практики ритуального благочестия, этого достаточно, чтобы причислить его к категории религий, даже если мы не обнаруживаем там аскетических практик, подобных монашеским практикам в христианстве. Если мы обнаруживаем в буддизме аскетические практики, то это уже (согласно принципу «семейного сходства») позволяет причислить буддизм к категории религий, даже если мы не обнаруживаем там ярко выраженного представления о связи людей с богами. Поскольку цель выработки конвенционального понятия религии состояла в том, чтобы отделить ее от сферы «мирского», «секулярного», постольку все остальные области социально-культурной жизни - политика, искусство, наука, труд, повседневные практики, развлечения и др. были исключены из понятия религии.

С недостатками такого понимания религии чаще всего сталкиваются антропологи и социологи, изучая как традиционные, так и современные общества, где религия занима- 
ет по большей части то положение, какое отводилось ей в средневековой Европе (равно как и в исторически и географически иных культурах). И, как выясняется, там, где люди встречаются со «сверхъестественным»и и «священным» и там, где они практикуют аскезу, они не так уж чужды игре.

\section{Историко-культурные прецеденты конвергенции религии и игры}

Нидерландский культуролог Йохан Хёйзинга со ссылкой на труды антропологов показывает, что священнодействие «разыгрывается, исполняется в пределах реально выделенного игрового пространства как подлинный праздник, то есть радостно и свободно» [Хёйзинга 2011, 40]. Й. Хёйзинга обращается за антропологическим материалом к книге А.Э. Йенсена «Церемонии обрезания и инициации у первобытных народов». Описанные здесь ритуалы показывают, что архаическому человеку, совершающему сакральные церемонии, вовсе не чужда «задняя мысль», что все это происходит «не взаправду» [Хёйзинга $2011,51]$. Мужчины - участники ритуала инициации, в полной мере играют, так как именно они «прописывают» сценарий ритуала, изготавливают ритуальные маски духов предков и распространяют леденящие кровь истории о жестокости этих духов и о жуткой судьбе тех, чьими действиями во время ритуала духи будут недовольны. Вместе с тем мужчины понимают, что ритуал инициации определяет дельнейшую судьбу общины, а значит к его проведению следует относиться со всей серьезностью. Настрой посвящаемых колеблется от экстатических состояний и глубокого страха до ребячливой бравады. Наиболее двойственно ведут себя женщины. С одной стороны, они хорошо осведомлены о закулисье ритуала и прекрасно знают, что их собственные мужья скрываются под личинами «духов предков», которые бродят по лесу во время инициации, ловят и испытывают юношей. С другой стороны, по описаниям антропологов, они с неподдельным ужасом разбегаются от людей в масках. Эта двойственность, можно заметить в дополнение, свойственна и ритуалам оплакивания. Плакальщицы, с одной стороны, вовлечены в горестный ритуал и зачастую впадают в скорбный экстаз, с другой - осознают, что выражаемая ими скорбь - не их скорбь. Хёйзинга полагает, что участники ритуала осознают запрет на «шпильбрехерство», то есть на действия, способствующие разрушению священной игры [Хёйзинга 2011, 52].

Ценный антропологический материал для изучения отношений между религиозными практиками и игрой дает Г. Бейтсон: «Когда на Бали шаман, называемый балиан, входит в состояние измененного сознания, он (или она) говорит голосом бога, выражаясь так, как это приличествует богу. И когда этот голос обращается к обычным взрослым смертным, он называет их “папа" или "мама". Ведь балийцы представляют себе отношения между богами и людьми как отношения между детьми и родителями, причем в этих отношениях боги - это дети, а люди - родители. Балийцы не ожидают от своих богов ответственности. Они не чувствуют себя обманутыми, если боги капризничают. Напротив, они радуются небольшим капризам и чарам, которые демонстрируют боги, временно воплощенные в шаманах. Как это непохоже на нашего дорогого библейского Иова!» [Бейтсон 2019, 57]. Получается, что сфера отношений человека с богами ассоциируется с детской игрой, боги играют с людьми, значит и последние оказываются вовлечены в игровые отношения с богами либо как партнеры, либо как игровой инвентарь. Подтверждает эти рассуждения и документальный фильм, снятый Г. Бейтсоном и его супругой - американским антропологом Маргарет Мид - «Транс и танец на Бали». Фильм посвящен балийской церемонии, представлению, во время которого разыгрывается рассказ о конфликте дракона и колдуньи. Постепенно сценическое действо переходит в танец, в ходе которого часть участников впадает в трансовое состояние. Причем транс оказывается настолько глубок, что приходится применять специальные средства для выведения из него. Для европейца антрополога в этой церемонии как бы перемешаны театрализованная игра и серьезный ритуал. Для балийца, по-видимому, здесь нет этой двойственности, он не видит противоречий между ритуалом и игрой. 


\section{ЧЕЛОВЕК И ОБЩЕСТВО В ПОСТСЕКУЛЯРНУЮ ЭПОХУ}

В приведенных выше примерах взгляды наблюдателя и наблюдаемых не совпадают. В каком-то смысле проблема совмещения игры и ритуала навязана взглядом антрополога, смотрящего из культуры, которая уже разграничила игру и ритуал. Весь антропологический пафос Йенсена, Бейтсона и Хёйзинги основан на удивлении от отсутствия этого разграничения в неевропейских культурах. Однако, если мы переместим наш взгляд в Древнюю Грецию, где зародилась философская культура различения и категориального мышления, мы и там столкнемся с подобным игнорированием границы игры и религии. Хёйзинга обращает внимание на выражение «священная игра», которое используется Платоном в диалоге «Законы» [Платон 1994]. Там же Платон устами своих персонажей предписывает гражданам идеального полиса играть в священные игры, то есть совершать жертвоприношения, петь, танцевать ${ }^{2}$. Примечательно, что у Платона религиозный ритуал стоит в одном ряду с тем, что мы без колебаний относим к области секулярного искусства. Однако для греков это не удивительно, если принять во внимание то, что они изобрели две формы, где игра и религия переплетаются до нерасторжимости - театр и спортивные игры. $\mathrm{C}$ одной стороны, хорошо известно, что и агонистика, и театр уходят своими корнями в религиозные ритуалы, посвященные традиционным древнегреческим богам. С другой, также известно, что, открепившись от исходных религиозных практик, и агон, и театр сохранили связь с ними: и состязаниям, и театральному действию предшествовало совершение жертвоприношений. Боги считались присутствующими и на состязаниях, и на театральном представлении, причем и то и другое связывалось с действиями конкретных божеств - Зевса, Посейдона, Аполлона, муз. Даже различив игру и серьезность (Платон называл единственным серьезным делом войну), греки сохранили религиозные практики в игровой зоне ${ }^{3}$.

Говоря о связи игры и религии, невозможно пройти мимо той критики, которую дал книге Хёйзинги, тому ее разделу, который посвящен религии, Роже Кайуа [Кайуа 2003, 266276]. Соглашаясь с тем, что ритуальная практика в традиционном обществе пересекается с игрой, Кайуа тем не менее настаивал на не- совместимости игры и сакрального. Эти области, по мысли Кайуа, отделены от повседневности (именно это, как полагает французский антрополог, и ввело Й. Хёйзингу в заблуждение), но находятся как бы по разные стороны от нее. Главное отличие состоит в том, что в игре человек свободен и самовластен: он в любой момент может войти и выйти из нее. Не так обстоят дела с сакральным: оно настигает человека и не сообразуется с его желаниями. Игра - это желанное состояние, в которое человек стремится при любой возможности погрузиться. Сакральное, напротив, ужасает и побуждает человека избегать встречи с ним без особой нужды. Эта критика, сама по себе интересная и плодотворная, несильно затрагивает наши рассуждения о смежности игры и религии, так как религия не исчерпывается отношением к сакральному. Как уже было показано, эта связь (связь между религией и сакральным) далеко не универсальна и свойственна по большей чести европейской культуре. Как показывают ранее приведенные примеры, сакральное мерцающим образом может присутствовать в религиозных ритуалах, а восприятие сакрального (трепет и завороженность) также мерцающим образом охватывает душу участника ритуала.

Возможно, трещина между игрой и религией начала разрастаться в христианской культуре, поскольку в христианстве мистерия «смерти бога (Бога)» была изъята из контекста аграрных оргиастических ритуалов, где смерть и рождение действительно шли рука об руку и в этой связи смерть не воспринималась столь драматично. Кроме того, эти оргиастические ритуалы никак не были связаны с аскезой греха и вины, взлелеянной христианским монашеством. Вместе с тем на протяжении всего Средневековья трещина, о которой идет речь, еще была вполне преодолима. Об этом свидетельствует наличие «карнавальной культуры», обстоятельно изученной М.М. Бахтиным.

Хотя М.М. Бахтин декларирует «внерелигиозность» карнавала [Бахтин 1990, 11] (нужно иметь в виду, что он специально не рассматривает понятие религии, а использует его в докритическом режиме), он специально заостряет внимание на временной и 
пространственной связи карнавального действа с христианскими праздниками и особенно с Пасхой [Бахтин 1990, 13]. Карнавал был связан с традицией религиозных праздников не только временем проведения, но и содержанием. Об этом свидетельствует традиция так называемого «пасхального смеха» («risus paschalis») - пародии на привычные для средневекового христианина элементы церковной ритуалистики. Практически все значимые формы церковных практик получают своих пародийных двойников в карнавальной традиции - «священные пародии» («parodia sacra»): существовали «Литургия пьяниц», «Литургия игроков» и др. [Бахтин 1990, 20]. Наиболее устойчивой и распространенной игровой формой (около-) религиозных практик был «праздник дураков». Первоначально он даже проходил в храмовых помещениях, затем, к концу Средневековья, был выдворен из храмов, но сохранялся на площадях, в тавернах. «Праздник дураков» включал в себя действия, пародировавшие официальный церковный культ [Бахтин 1990, 86-87]. Не менее ярким примером игровой религиозности был «праздник осла», приуроченный к церковному празднику воспоминания о бегстве святого семейства в Египет. Существовала целая пародийная месса, в которой возглас «Amen» заменялся имитацией ослиного крика «Hinham» [Бахтин 1990, 90].

Бахтин специально подвергает критике сложившееся в эпоху Просвещения толкование этого смеха как сатирического, критического. В карнавале не было четко выраженного социального протеста против культуры «господствующего класса»: представители церковной, ученой и феодальной элиты сами были вовлечены в карнавальное действо и отнюдь не брезговали шутками, в том числе и в адрес своего сословия [Бахтин 1990, 19, 133]. Также неверно было бы видеть в смеховой культуре Средневековья антиклерикальные мотивы. Смех в орудие борьбы с клерикализмом превратили как раз деятели эпохи Просвещения. М.М. Бахтин убедительно показывает это на примере восприятия творческого наследия Ф. Рабле во Франции (и не только). Именно в эпоху Просвещения смех $\Phi$. Рабле начинает восприниматься как антиклерикальный и социально-протестный, и эта традиция толкования Ф. Рабле сохранялась вплоть до XX в. - века великих идеологий.

Именно эпоха Просвещения, по-видимому, стала временем, когда в Западной Европе происходит секуляризация игры. Сначала этот процесс затронул элиту, которая стала вырабатывать особые развлекательные практики (наподобие ассамблей, учрежденных в России Петром Первым). Балы и состязания заполнили ту часть души, которая нуждалась в игровых практиках. В народной культуре связь между игрой и религией была устойчивее. Религиозные праздники сохраняли остатки сакрального характера игр. В конце концов, именно церковные действия вносили в народный быт Европы элемент развлекательности, игры. До сих пор для определенной категории верующих воскресное посещение церкви представляет собой нечто вроде развлечения, которое считается более «духовным», чем, скажем, просмотр телевизионной программы.

Однако секуляризация культуры, разграничив игру и религию, парадоксальным образом подготовила условия для их сближения. Это неудивительно, если понимать секуляризацию не как упадок религиозности вообще, а как кризис институциональной религиозности, снижение влияния церковных институтов на повседневную жизнь человека. Освобождающаяся из-под церковной опеки религиозность стала принимать самые причудливые формы и вступать в альянс с теми видами деятельности, которые модерн конституировал в качестве секулярных.

\section{Зоны конвергенции религии и игры в современной культуре}

В современной культуре сопряжение игры и религии в явном или неявном виде можно наблюдать в сферах новых религиозных движений, индустрии развлечений, спорта.

В области новых религиозных движений наиболее заметен игровой компонент там, где практикуют литературно-кинематографический косплей и пародируют традиционные религиозные институты [Гаврилов 2015]. Яркий пример первого - «джедаизм». Это движение сформировано поклонниками киноэпопеи «Звездные войны». Долгое время оно никак не проявляло своей «религиозности» и пред- 


\section{ЧЕЛОВЕК И ОБЩЕСТВО В ПОСТСЕКУЛЯРНУЮ ЭПОХУ}

ставляло собой совокупность никак не связанных друг с другом клубов по интересам, разыгрывавших костюмированные представления по мотивам фильмов Джорджа Лукаса. Однако в 2001 г. в Великобритании, а также в ее бывших доминионах - Австралии и Новой Зеландии, во время очередной переписи населения многие в графе «религия» написали «джедаизм» (или «джедай»). Причем численность «джедаев» (в Британии и Уэльсе около 400000 чел.) потребовала от Министерства юстиции внесения этой «религии» в перечень исповеданий как новое религиозной движение «Рыцарь Джедай» ${ }^{4}$. Спустя несколько лет в США была зарегистрирована религиозная некоммерческая благотворительная организация «Храм ордена джедаев» [Сафронов 2019]. Это означает, что «джедаи» могут получить юридические полномочия, которыми пользуются другие религиозные организации, скажем, регистрировать браки, то есть проводить церемонии, которые в американском обществе считаются по существу религиозными. Отсутствие единой организационной структуры, канонизированного обряда, догматики, а также богообщения, как было показано выше, еще не является основанием для того, чтобы рассматривать это движение как нерелигиозное. Примерно в то же время, что и «джедаизм», но по другим причинам возникло пародийное новое религиозное движение - пастафарианство, представленное «Церковью макаронного монстра». Основатель этой организации Роберт Хендерсон - американский ученый и правозащитник. Стимулом для создания пастафарианства стали дебаты вокруг закона одного из Северо-Американских штатов о преподавании в школе креационизма наряду с эволюционной концепцией. Сторонники этого закона утверждали, что обе «теории» эпистемологически равноценны (то есть имеют аргументы в свою пользу, но не имеют окончательного подтверждения) и на этом основании они в равной мере должны быть представлены в образовательных программах. Хендерсон попытался свести эту аргументацию к абсурду: он написал письмо в школьный комитет (School Board) штата Канзас, в котором предлагал ввести в школе предмет изучающий «теорию», согласно которой мир был создан Летающим Макаронным Мон- стром, существование которого так же нельзя опровергнуть (и доказать), как и существование Бога авраамических религий. Хендерсон снабдил свое письмо подписями его сторонников (которые, как и Хендерсон, были противниками введения креационистской концепции в школе). Идея Хендерсона получила развитие в юридической практике США, а затем и других стран. Религия Макаронного Монстра стала использоваться как своеобразный правовой пробный камень. Так, гражданин Австрии сумел добиться права сфотографироваться на водительское удостоверение в дуршлаге (после того, как было разрешено фотографироваться в головном уборе по религиозным соображениям). В итоге пастафарианство стало популярным, во многом благодаря интернету. Существуют национальные пастафарианские церкви с собственными интернетсайтами, на которых публикуются «вероучительные» документы, новости, касающиеся пастафарианских праздников, избрания или назначения руководителей организаций и т. п. ${ }^{5}$

Форму религиозного косплея зачастую принимают практики «неоязычников». Как идейная оснастка, так и собрания неоязычников, несут на себе печать реконструкции. Небеспочвенно создается впечатление, что участники неоязыческих общин в большей степени вдохновлены воссозданием древних ритуалов (как они считают, репрессированных христианством), чем мотивами, считающимися специфически религиозными - аскезой, мистическими исканиями, богообщением. Знакомство, например, с мероприятиями неоязыческого движения «Родноверие» наталкивает на аналогии между языческими праздниками и реконструкторскими собраниями [Родноверие web]. Этот игровой компонент усиливается после того, как был ослаблен политический подтекст неоязычества, связанный в России 1990-х гг. с националистической идеологией [Шнирельман (ред.) 2001, 15]. Именно кристаллизация политического поля России в 2000-е гг. привела к тому, что неоязычество утратило силу своей идеологической харизмы и трансформировалось в очередную субкультуру с религиозной спецификой. Впрочем, нет оснований утверждать, что от этих процессов застрахованы и традиционные конфессии. Распространение виртуаль- 
ных и невиртуальных игровых практик - характерная черта так называемого «постмодерна» - пронизывает все тело современной культуры.

Впечатляющий пример взаимопроникновения религиозных и игровых практик дает послевоенная поп-культура, в особенности ее музыкальный сегмент. Глубинные и поверхностные связи рок-музыки с религиозными традициями и инновациями уже стали предметом исследовательского внимания [Тернер 2001]. Меньше внимания обращается на то, что рок-культура стала субститутом традиционных форм религии. Нетрудно убедиться в том, что и по свой композиции, и по психическому состоянию участников стадионные рок-концерты эквивалентны религиозным ритуалам. Однако помимо этих параллелей впечатляет еще и то, насколько отграничен хронотоп концертного действа от остальных областей жизненного мира участников этих ритуалов. Во многих случаях серьезные вербальные послания музыкантов тонут в общей атмосфере развлечения. По-видимому, этим объясняется тот парадоксальный на первый взгляд эффект, что протестный потенциал рок-культуры оказался без труда апроприирован шоу-бизнесом, а пафос разоблачения общества потребления, свойственный творчеству многих рок-музыкантов, был поставлен на службу самому консьюмеризму. Поэтому религиозные искания рокеров, идолопоклонство фанатов и экстатические ритуалы рок-концертов хорошо монтируются с общей атмосферой игры. Разумеется, как и любая игра с высокими ставками, она не отделена непроходимым рвом от неигровой реальности. Однако даже неигровые явления (такие как смерть кумира от передозировки наркотиков или суицида) также встроены в этот игровой контекст.

Неочевидный пример конвергенции игры и религии дает спорт, если понимать это явление предельно широко и включать в понятие спорта не только действия спортсменов на арене, но и весь окружающий контекст: одержимость любителями спорта информацией о результатах состязаний и судьбе спортсменов, фан-клубы и церемонии, сопровождающие спортивные игры (здесь приходят на память квазирелигиозные церемонии открытия игр олимпиад, чемпионатов). Британский исследо- ватель религии Грэм Харви, рассуждая о понятии религии, приводит шутливый пример тестового вопроса, который можно задать любому автору такой дефиниции: «являются ли буддизм и футбол религиями?» Этот вопрос приобретает толику серьезности, если далее ознакомиться с понятием футбола: «Площадка для конструирования сообществ, коллективно проходящих через сильные переживания и ритуализирующих свое отношение к героям и спортивным “идолам"» [Харви 2020, 332]. Нетрудно заметить, что при таком понимании фугбол вполне попадает в категорию религии в ее социально-психологическом понимании. Разумеется, некоторыми оговорками можно отделаться от этого «абсурдного» предположения. Тем не менее они не отсекают возможности найти параллели между религией (в привычном понимании) и спортивной игрой. Тем более, что у спорта и религии общие корни, восходящие к архаическим ритуализированным (как правило, гадательным) практикам состязаний.

\section{Заключение}

Указанием на наиболее заметные зоны конвергенции религии и игры в современной постсекулярной ситуации, разумеется, не исчерпывается рассмотрение предмета. На наш взгляд, стирание границ между религией и игрой соответствует «духу времени», который удачно схвачен концептами «постирония〉 и «новая искренность» [Konstantinou 2016; Hoffman 2016; Никулина 2018; Павлов 2019]. Ирония, эта дочь романтической реакции на классицизм, еще указывает на границу смехового хронотопа, хотя сама является пограничным явлением (серьезность явленного означающего и юмористичность контекста). Постирония - гораздо более тонкий и неоднозначный прием, который, в отличие от иронии, не имеет конвенционально установленного контекста. Когда автор высказывания иронизирует над иронией, то он, вольно или невольно, вызывает эффект, подобный тому, что называется «мизанабим» - поставленным друг напротив друга зеркалам с уходящей в них головокружительной перспективой. Адресат просто не способен однозначно считать смысл сообщения - шутит автор или говорит всерьез. Это напоминает приведенный выше пример ритуала инициации, участни- 
ки которого одновременно серьезны и несерьезны. Впрочем и автор также находится в ситуации двойственности. Что такое перформанс в храме - политическая акция или инфантильное баловство, дискредитация религиозного института, «оскорбление чувств верующих» или очищение религиозной общины от лицемерия и низкопоклонства? Возможно, у этого перформанса и не было предзаданного значения. Решение суда, квалифицировавшее это как правонарушение, похоже на эффект наблюдателя в квантовой физике - коллапс волновой функции. В ситуации постиронии участник социальных процессов не застрахован и от того, что даже официальное решение содержит в себе ироничный (постироничный) подтекст. Не случайна апелляция в дискуссиях по поводу подобных конфликтных ситуаций к практикам премодерна, а именно к феномену юродства. Действительно, юродивые балансировали на грани смеха и гнева [Иванов 2005].

Возможно также, что привыкшая к серьезности тона в эпоху модерна классическая религия пытается вернуть себе внимание аудитории посредством «новой искренности». Однако быть искренним в эпоху постмодерна - гарантированное средство лишиться аудитории. Ведь для постмодерна искренность находится где-то на пересечении непристойности, пошлости и тоталитаризма. То есть игра - один из путей, по которому религия возвращается в мир, который устал от серьезности секуляризации.

\section{ПРИМЕЧАНИЯ}

\footnotetext{
${ }^{1}$ Цитируемый отрывок находится в лекции № 1.

${ }^{2} \mathrm{O}$ значении игры для греческой религии см.: [Пигалев 2001, 351].

${ }^{3}$ О творческой роли смеха в мифологии см.: [Пропп 1976, 174-204].

${ }^{4}$ В англоязычной «Википедии» целая статья «Jedi census phenomenon» посвящена этому событию [Jedi... web].

${ }^{5}$ См., например, сайт российских пастафариан: [Русская Пастафарианская Церковь web].
}

\section{СПИСОК ЛИТЕРАТУРЫ}

Бахтин 1990 - Бахтин М.М. Творчество Франсуа Рабле и народная культура средневековья и
Ренессанса. М.: Художественная литература, 1990.

Бейтсон 2019 - Бейтсон Г., Бейтсон М.К. Ангелы страшатся. М.: АСТ, 2019.

Витгенштейн 1994 - Витгенштейн Л. Философские работы. В 2 ч. Ч. 1. М.: Гнозис, 1994.

Гаврилов 2015 - Гаврилов Е.О. Игровая религиозность как репрезентант современных тенденций социального развития // Вестник Кемеровского государственного университета. 2015. T. 4, № 2 (62). С. 193-198.

Джеймс 2017 - Джеймс У. Многообразие религиозного опыта. Исследование человеческой природы. М.: Академ. проект, 2017.

Иванов 2005 - Иванов С.А. Блаженные похабы: Культурная история юродства. М.: Яз. слав. культур, 2005.

Иллка Пюсиайнен web-Илкка Пюсиайнен. Как работает религия: на пути к новому когнитивному религиоведению // https://religious. life/2013/04/pyysiainen/.

Кайуа 2003 - Кайуа Р. Миф и человек. Человек и сакральное. М.: ОГИ, 2003.

Лакофф 2011 - Лакофф Дж. Женщины, огонь и опасные вещи: что категории языка говорят нам о мышлении. М.: Гнозис, 2011.

Никулина 2018 - Никулина А.К. «Написать весь мир заново»: ирония и постирония в романе Дэвина Марксона «Любовница Витгенштейна» // Вестник Башкирского государственного педагогического университета им. М. Акмуллы. 2018. № 2 (46). С. 93-99.

Отто 2008 - Отто Р. Священное. Об иррациональном в идее божественного и его соотношении с рациональным. СПб.: Изд-во С.-Петерб. ун-та, 2008.

Павлов 2019 - Павлов А.В. Дивный, новый «цифровой мир»: постирония как ценностная установка мировоззрения миллениалов // Горизонты гуманитарного знания. 2019. № 3. С. 16-31.

Пигалев 2001 - Пигалев А.И. Культура как целостность. (Методологические аспекты). Волгоград: Изд-во ВолГУ, 2001.

Платон 1994 - Платон. Собрание сочинений. В 4 т. Т. 4. М.: Мысль, 1994.

Пропп 1976 - Пропп В.Я. Фольклор и действительность. М.: Наука, 1976.

Родноверие web - Родноверие // http://www. rodnoverie.org.

Русская Пастафарианская Церковь web - Русская Пастафарианская Церковь // http://www.rpcmp.ru.

Сафронов 2019 - Сафронов Э. Популярная культура как религия // Государство, религия, церковь в России и за рубежом. 2019. № 3. С. 277283. DOI: https://doi.org/10.22394/2073-72032019-37-3-277-283. 
Тернер 2001 - Тернер С. Лестница в небеса. М.: Триада, 2001.

Харви 2020 - Харви Г. Секс, еда и незнакомцы. Религия как повседневная жизнь. М.: НЛО, 2020.

Хёйзинга 2011 - Хёйзинга Й. Ноomo Ludens. Человек играющий. СПб.: Изд-во Ивана Лимбаха, 2011.

Шнирельман (ред.) 2001 - Шнирельман В.А. (ред.). Неоязычество на просторах Евразии. М.: Изд-во ББИ, 2001.

Dubuisson 2003 - Dubuisson D. The Western Construction of Religion: Myths, Knowledge, Ideology. Baltimore: The John Hopkins University Press, 2003.

Hoffman 2016 - Hoffman L. Postirony. The Nonfictional Literature of David Foster Wallace and Dave Eggers. Bielefeld: Gazelle Book Service, 2016.

Jedi... web - Jedi Census Phenomenon // https://en. wikipedia.org/wiki/Jedi_census_phenomenon.

Konstantinou 2016 - Konstantinou L. Cool Characters: Irony and American Fiction. Cambridge: Harvard University Press, 2016.

McCutcheon 1997 - McCutcheon R. T. Manufacturing Religion: The Discourse on Sui Generis Religion and the Politics of Nostalgia. N. Y., Oxford: Oxford University Press 1997.

Rosenstock-Huessy 2005 - Rosenstock-Huessy E. Comparative Religion // The Collected Works of Eugen Rosenstock-Huessy on DVD. Norwich: Argo Books, 2005.

\section{REFERENCES}

Bakhtin M.M., 1990. The Work of Francois Rabelais and the Folk Culture of the Middle Ages and the Renaissance. Moscow, Khudozhestvennaya literatura Publ.

Bateson G., Bateson M.K., 2019. Angels are Afraid. Moscow, AST Publ.

Wittgenstein L., 1994. Philosophical Works. In 2 pt. Pt. I. Moscow, Gnosis Publ.

Gavrilov E.O., 2015. Game Religiosity As a Representative of Modern Trends in Social Development. Vestnik Kemerovskogo Universiteta, vol. 4, no. 2 (62), pp. 193-198.

James W. 2017. The Diversity of Religious Experience. The Study of Human Nature. Moscow, Academicheskiy project Publ.

Ivanov S.A. 2005. Blessed Pokhabs: The Cultural History of Foolishness. Moscow, Yazyki slavyanskikh kultur Publ.

Illka Pyysiäinen. How Religion Works: Towards a New Cognitive Science of Religion. URL: https:// religious.life/2013/04/pyysiainen/.
Kayua R., 2003. Myth and Man. Man and the Sacred. Moscow, OGI Publ.

Lakoff J., 2011. Women, Fire and Dangerous Things: What the Categories of Language Tell Us About Thinking. Moscow, Gnosis Publ.

Nikulina A.K., 2018. "To Write the Whole World Anew": Irony and Post-Irony in Devin Markson's Novel "Wittgenstein's Mistress". Vestnik Bashkirskogo Gosudarstvennogo Pedagogicheskogo Universiteta imeni M. Akmully, no. 2 (46), pp. 93-99.

Otto R., 2008. Sacred. On the Irrational in the Idea of the Divine and its Relation to the Rational. Saint Petersburg, St. Petersburgrkiy Universitet Publ.

Pavlov A.V., 2019. Brave New "Digital World": PostIrony as a Value Setting of the Millennials' Worldview. Horizonty Gumanitarnogo Znaniya, no. 3, pp. 16-31.

Pigalev A.I., 2001. Culture as Totality. (Methodological Aspects). Volgograd, Volgogradskiy Universitet Publ.

Plato, 1994. Collected Works. In 4 Vols. Vol. 4. Moscow, Mysl Publ.

Propp V.Ya., 1976. Folklore and Reality. Moscow, Nauka Publ.

Rodnoverie. URL: http://www.rodnoverie.org.

Russian Pastafarian Church. URL: http://www. rpcmp.ru.

Safronov E., 2019. Popular Culture As a Religion. Gosudarstvo, religiya, tserkov v Rossii i za rubezhom, no. 3, pp. 277-283. DOI: https://doi. org/10.22394/2073-7203-2019-37-3-277-283.

Turner S., 2001. Stairway to Heaven. Moscow, Triada Publ.

Harvey G., 2020. Sex, Food and Strangers. Religion as Everyday Life. Moscow, Novoye Literaturnoye Obozreniye Publ.

Huizinga J. 2011. Homo Ludens. A Man Playing. Saint Petersburg, Ivan Limbach Publ.

Shnirelman V.A. (ed.), 2001. Neo-Paganism in the Expanses of Eurasia. Moscow, BBI Publ.

Dubuisson D., 2003. The Western Construction of Religion: Myths, Knowledge, Ideology. Baltimore, The John Hopkins University Press.

Hoffman L., 2016. Postirony. The Nonfictional Literature of David Foster Wallace and Dave Eggers. Bielefeld, Gazelle Book Service.

Jedi Census Phenomenon. URL: https://en.wikipedia. org/wiki/Jedi_census_phenomenon.

Konstantinou L., 2016. Characters: Irony and American Fiction. Cambridge, Harvard University Press.

McCutcheon R.T., 1997. Manufacturing Religion: The Discourse on Sui Generis Religion and the Politics of Nostalgia. New York, Oxford, Oxford University Press.

Rosenstock-Huessy E., 2005. Comparative Religion. The Collected Works of Eugen RosenstockHuessy on DVD. Norwich, Argo Books. 
ЧЕЛОВЕК И ОБЩЕСТВО В ПОСТСЕКУЛЯРНУЮ ЭПОХУ

\section{Information About the Author}

Dmitriy R. Javorskiy, Doctor of Sciences (Philosophy), Associate Professor, Professor, Department of Philosophy, Volgograd State University, Prosp. Universitetsky, 100, 400062 Volgograd, Russian Federation, d.r.yavorsky@yandex.ru, https://orcid.org/0000-0002-9198-4847

\section{Информация об авторе}

Дмитрий Ромуальдович Яворский, доктор философских наук, доцент, профессор кафедры философии, Волгоградский государственный университет, просп. Университетский, 100, 400062 г. Волгоград, Российская Федерация, d.r.yavorsky@yandex.ru, https://orcid.org/0000-0002-9198-4847 